\title{
Large abscesses on the border of segment VII and VIII of the liver treated effectively pharmacologically - empirically chosen antibiotic therapy for a patient with diabetes
}

\author{
Duże ropnie na granicy segmentu VII i VIII wątroby leczone skutecznie \\ farmakologicznie - empirycznie dobrana antybiotykoterapia - u chorego \\ na cukrzycę
}

\author{
Marta Malinowska², Beata P. Kraśnicka-Sokół², Krzysztof Filczak², Marek Kochmański \\ ${ }^{13}{ }^{\text {rd }}$ Department of Internal Medicine, Subdivision of Toxicology, AZA Treatment Subdivision, Subdivision of Nephrology, Praski Hospital \\ of the Transfiguration of Jesus, Warsaw, Poland \\ Head of the Department: Beata Kraśnicka-Sokół MD, PhD (till: 31.01.2015) \\ ${ }^{2}$ Department of Bacteriology, Central Clinical Hospital Ministry of Interior and Administration, Warsaw, Poland \\ Head of the Department: Małgorzata Cicha MD, PhD \\ 3UWMSC - Maria Sklodowska-Curie Warsaw University, Warsaw, Poland \\ Head of the UWMSC: Mirosław Cienkowski PhD
}

Key words: fever, liver abscess, antibiotic therapy.

Słowa kluczowe: stany gorączkowe, ropnie wątroby, antybiotykoterapia.

\begin{abstract}
Liver abscesses are focal necroinflammatory lesions of bacterial, fungal, or amoebic origin. Pharmacological treatment is rarely sufficient if negative blood cultures are present. The report presents the case of a 62-year-old man with hypertension and type 2 diabetes, diagnosed with liver abscesses. The patient received two-stage empirical antibiotic therapy. Firstly in the hospital setting - cefuroxym, gentamicin, and metronidazole. After a 10-fold reduction in C-reactive protein and clinical improvement the patient was discharged home. In the second stage - ceftibutyn, metronidazole, and fluconasol were used in the outpatient setting. During rehospitalisation, a significant reduction in the size of abscesses was noted. The patient was twice consulted bacteriologically (treatment was accepted) and his computed tomography (CT) scans were sent for surgical consultation, which confirmed the effectiveness of the drug treatment and did not qualify for surgical treatment. In the 8-month follow-up there was no relapse and CT scans showed only scarring of the liver.
\end{abstract}

\section{Streszczenie}

Ropnie wątroby są zmianami ogniskowymi miąższu wątroby o etiologii bakteryjnej, amebowej lub grzybiczej. Rzadko udaje się je wyleczyć jedynie metodą farmakologiczną przy ujemnych wynikach posiewów krwi. W pracy przedstawiono przypadek 62-letniego mężczyzny leczącego się z powodu nadciśnienia tętniczego i cukrzycy typu 2, u którego rozpoznano ropnie wątroby. U chorego zastosowano dwuetapową antybiotykoterapię empiryczną. W pierwszym etapie (złożona antybiotykoterapia) w warunkach szpitalnych podawano cefuroksym, gentamycynę i metronidazol. Po 10-krotnej redukcji wartości stężenia białka C-reaktywnego oraz uzyskaniu poprawy klinicznej pacjenta wypisano do domu. W drugim etapie leczenia (ambulatoryjnym) stosowano ceftibutyn, metronidazol i flukonazol. Przy ponownej hospitalizacji stwierdzono znaczne zmniejszenie wymiaru ropni wątroby. Przypadek konsultowano 2 razy bakteriologicznie (zaakceptowano leczenie), a wyniki badań obrazowych przesłano na konsylium chirurgiczne, gdzie potwierdzono skuteczność leczenia farmakologicznego i nie zakwalifikowano chorego do leczenia operacyjnego. W obserwacji 8-miesięcznej nie stwierdzono nawrotu choroby, a w obrazie tomografii komputerowej jamy brzusznej opisano jedynie zmiany bliznowate w wątrobie.

\section{Introduction}

Liver abscesses are focal necroinflammatory lesions of bacterial (pyogenic liver abscess - PLA), amoebic (amoebic liver abscess - ALA), or fungal origin.
They occur from biliary disease, as a result of the portal system, via the hepatic artery and adjacent organs. The most frequent aetiologic agents are anaerobic bacteria such as Klebsiella, Streptococcus, Pseudomonas, and Escherichia [1-10]. Clinical symptoms are unspecific. 

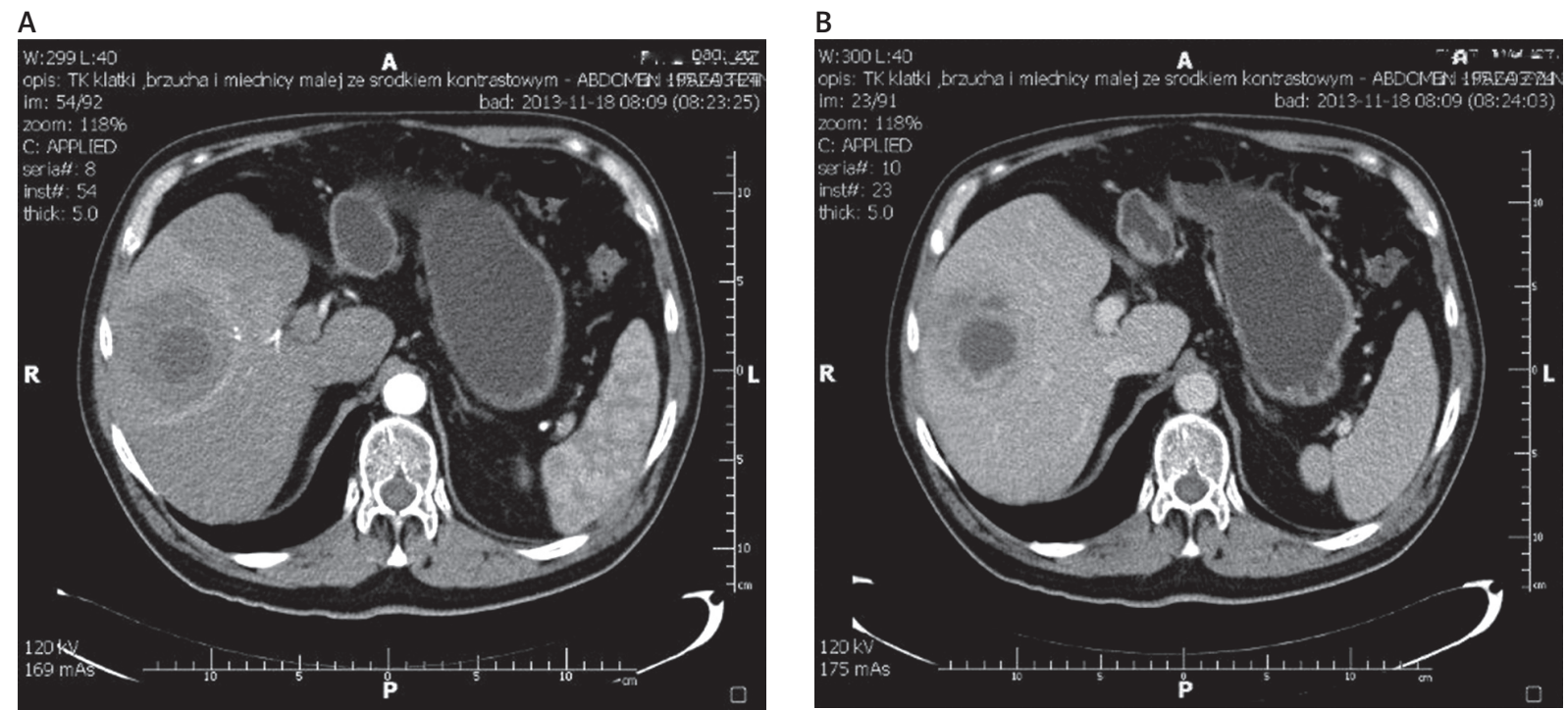

Figure $1 \mathrm{~A}, \mathrm{~B}$. Computed tomography before treatment

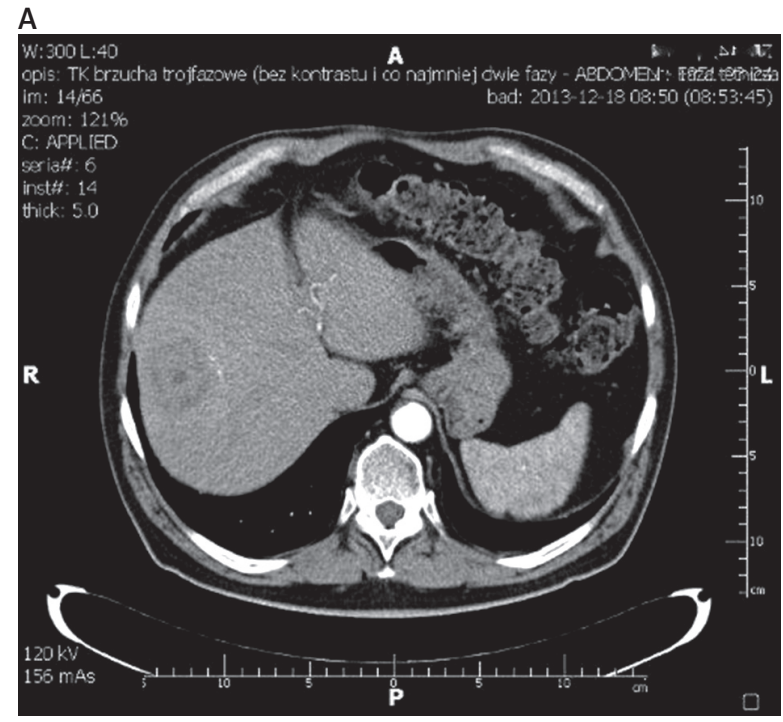

B

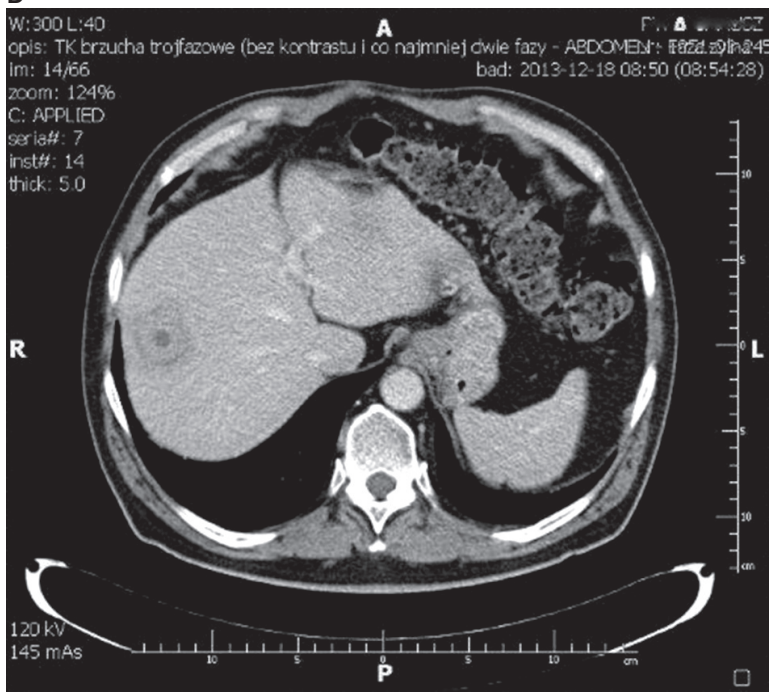

Figure $2 \mathrm{~A}, \mathrm{~B}$. Computed tomography during treatment

They include high fever and right upper quadrant abdominal pain. They may also be nausea, vomiting and jaundice. In laboratory tests the following are noted: leucocytosis, anaemia, elevated liver enzymes, and elevated C-reactive protein reaction (CRP) levels. Blood cultures are positive in $50 \%$ of cases [5]. The diagnosis is based on laboratory tests and imaging studies - abdominal ultrasound and/or computed tompography (CT) scans. Liver abscesses are usually situated in the right liver with diameters of $1.4-9.5 \mathrm{~cm}$ (average: $4.5 \mathrm{am}$ ), round in shape, and well separated from the liver tissue. Treatment depends on the clinical condition of the patient, and the size and location

of the abscesses. In most of patients combination therapy is used - antibiotics and percutaneous treatment (aspiration or drainage). This method of treatment is currently the recommended procedure because of its effectiveness and safety - it is a minimally invasive procedure and does not require general anaesthesia. According to some authors percutaneous drainage is essential in the treatment of liver abscesses [3]. The most common causes of this treatment failure are multiple abscesses, abscesses of large size with thick wall and technical difficulties. In cases of failure of the percutaneous drainage the treatment is based on surgery and antibiotic treatment. However, surgery 
A

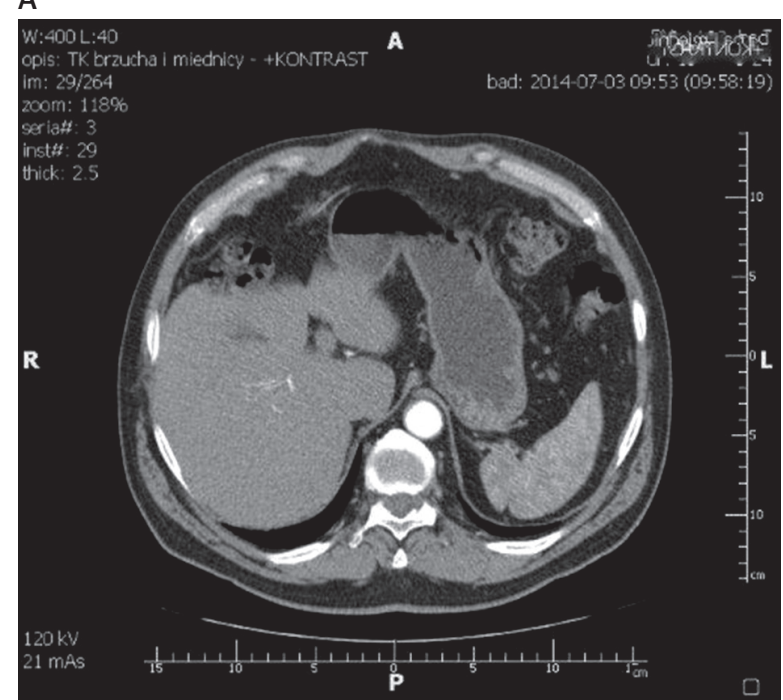

B

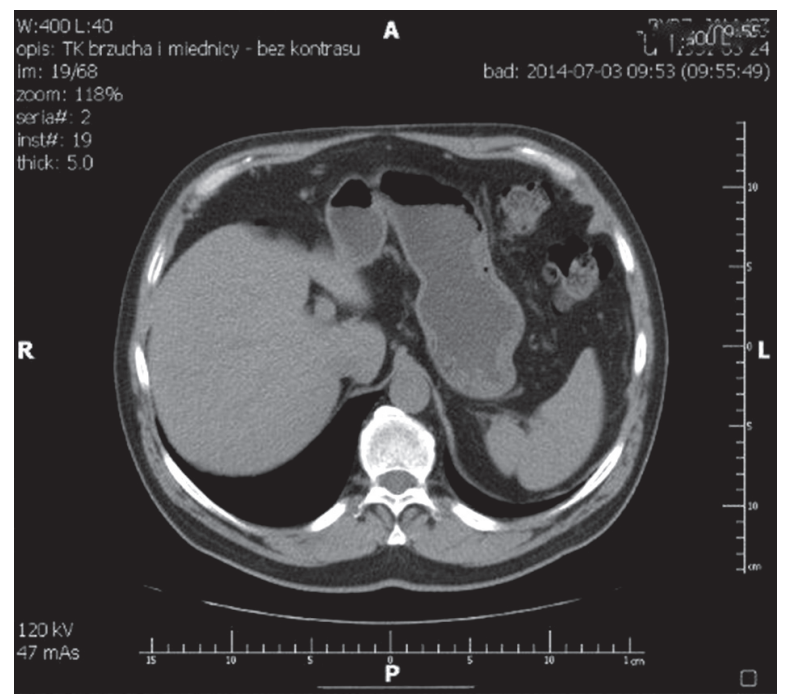

Figure 3 A, B. Computed tomography after treatment

should not be considered only as a second-line treatment. The urgent laparotomy is the standard therapy in a case when appear abscess rupture into the peritoneal cavity and concomitant pathologies. Some authors agree that surgery must be implemented as a first-line treatment in patients with a high risk of death in order to increase their chances of survival [2]. The mortality rate of untreated pyogenic liver abscess is nearly $100 \%$.

\section{Case report}

A 62-year-old man with type 2 diabetes treated with oral medications, hypertension and psoriasis was admitted to the Department because of fever lasting from 2 weeks with concomitant loss of body weight $(5 \mathrm{~kg})$ and high glucose levels in the blood. On admission the patient was cardiopulmonarily and respiratorily stable. On physical examination no abnormalities were found. In laboratory tests increased concentrations of CRP (242.3 mg/l) with slightly higher leucocytosis (WBC $11.1 \mathrm{k} / \mu \mathrm{l}$ ) were observed. Blood and urine cultures were without any signs of bacterial growth. The concentration of pro-calcitonin was $0.24 \mathrm{ng} / \mathrm{ml}$. The patient had abdominal ultrasound, which revealed two focal lesions in the right lobe of the liver, located next to each other with reduced echogenicity. In addition, the liver was not enlarged and had normal echogenicity. The abdominal CT with contrast was performed, which showed two focal lesions with the appearance of abscesses on the border of liver segments VII and VIII, measuring $44 \times 55 \mathrm{~mm}$ and $67 \times 68 \mathrm{~mm}$. There were no other abnormalities on the CT scans. Visceral and retroperitoneal lymph nodes were not enlarged. In echocardiography there was no infective endocarditis features or abscesses in the muscle of the left ventricle. Since the beginning of hospitalisation the patient received empirical broad-spectrum antibiotics (cefuroxime) to which were added in the following days gentamicin and metronidazole. During the treatment the patient had no high fever. After the reduction in CRP (23 mg/l), normalisation of leukocyte count, and good glycaemic control, the patient was discharged home with the recommendation to continue therapy with metronidazole, ceftibuten, and fluconazole. After about 4 weeks, still during the antibiotic treatment, the patient was again admitted to the Department to assess the effectiveness of treatment. In laboratory studies there were no significant abnormalities beyond slightly elevated levels of CRP (6.6 mg/l in norm to $5 \mathrm{mg} / \mathrm{l})$. Computer tomography confirmed the reduction in the dimensions of liver abscesses to $47 \times 35 \mathrm{~mm}$ and a diameter of $23 \mathrm{~mm}$. Abscesses had a thick wall and a small amount of fluid in the central portion. The patient was consulted by a surgeon and was not qualified to surgery. Percutaneous drainage was left to consider, from which the patient was disqualified by a radiologist. In view of the substantial thickness of the walls of abscesses, the use of multiple antibiotics, broad spectrum, normal markers of inflammation, and after further bacteriological consultation it was decided not to continue antibiotic treatment. Eight months after identification of the liver abscesses the patient was readmitted to the Department.

In the controls, abdominal computed tomography was performed at the location of the previously identified abscesses, revealing hypodense of liver tissue - lesions of diameter of approx. $19 \mathrm{~mm}$ and $15 \mathrm{~mm}$ 
corresponding to scarring of the liver. The CT pictures present changes in stages before treatment (Figure 1), during treatment (Figure 2), after treatment (Figure 3) (each CT shows the arterial and venous phase).

\section{Discussion}

Percutaneous drainage under ultrasound guidance is essential in the treatment of pyogenic liver abscesses. Many authors believe that it is not possible to cure permanently patients with liver abscesses only by pharmacological treatment [3]. It is especially difficult for patients with diabetes [11] taking into account the negative blood cultures collected several times [12]. Empiric broad-spectrum antibiotics are recommended initially until culture results are available. No randomised controlled studies have evaluated the optimal duration of antibiotic therapy for pyogenic liver abscess. Typical duration of antibiotic therapy is at least 4 to 6 weeks $[5,9]$. The effectiveness of such treatment is uncertain and requires the control of inflammatory marker tests, imaging studies (in the case described above the abdominal CT were performed thrice). Importantly, radiologic abnormalities resolve more slowly than clinical and biochemical features. Abscesses smaller than $10 \mathrm{~cm}$ can take up to 16 weeks to resolve. In this case it is extremely important to work with a microbiologist, and to have the possibility of surgical consultation [13]. Infectious disease, gastroenterology, interventional radiology, and general surgical consultations are recommended for any patient with hepatic abscess [5]. Empirically chosen antibiotic therapy was carried out including frequent measurements of the risk index IR, enabling effective use of the therapy [14].

\section{Conflict of interest}

The authors declare no conflict of interest.

\section{References}

1. Krawczyk M. Wątroba. In: Chirurgia. Noszczyk W (ed.). Wydawnictwo Lekarskie PZWL, Warsaw 2007; 782-820.

2. Alkofer B, Dufay C, Parienti JJ, et al. Are pyogenic liver abscesses still a surgical concern? A western experience. HPB Surg 2012, Article ID 316013.

3. Wang CL, Guo XJ, Qiu SB, et al. Diagnosis of bacterial hepatic abscess by CT. Hepatobiliary Pancreat Dis Int 2007; 6: 271-5.

4. Rajender Reddy K. Bacterial, parasitic, fungal, and granulomatous liver disease. In: Goldman's Cecil Medicine. Goldman L, Schafer AI (eds.). Elsevier, Philadelphia 2012; 987-96.

5. Ali T. Absces, liver. In: Ferri's Clinical Advisor 2015. Ferri FF (ed.). Elsevier, Philadelphia 2015; 12-3.

6. Yu SC, Ho SS, Lau WY, et al. Treatment of pyogenic liver abscess: prospective randomized comparison of catheter drainage and needle aspiration. Hepatology 2004; 39: 932-8.
7. Chan DSG, Archuleta S, Llorin RM, et al. Standardized outpatient management of Klebsiella pneumoniae liver abscesses. Int J Infect Dis 2013; 17: 185-8.

8. Tian LT, Yao K, Zhang XY, et al. Liver abscesses in adult patients with and without diabetes mellitus: an analysis of the clinical characteristics, features of the causative pathogens, outcomes and predictors of fatality: a report based on a large population, retrospective study in China. Clin Microbiol Infect 2012; 18: 314-30.

9. Balck SM, Prabhakaran S, Vickers SM. Liver abscess. In: Shackelford's Surgery of the Alimentary Tract. Yeo ChJ (ed.). Elsevier, Philadelphia 2013; 1464-78.

10. Herrera JL, Knudsen CD. Liver abscess. GI/Liver Secrets Plus, 2015; 237-42.

11. Kasiukiewicz A, Wojszel ZB. Infective endocarditis - clinical presentation and therapy in older people. Postępy Nauk Medycznych 2011; 8: 658-65.

12. Mocchegiani R, Nataloni M. Complications of infective endocarditis. Cardiovasc Hematol Disord Drug Targets 2009; 9: 240-8.

13. Habib G, Hoen B, Tornos P, et al. Guidelines on the prevention, diagnosis and treatment of infective endocarditis (new version 2009). The task force on the prevention, diagnosis and treatment of infective endocarditis of the ESC. Eur Heart J 2009; 30: 2369-413.

14. Kraśnicka-Sokół B, Kochmański M, Filczak K. Prognostic useful of the new risk index for infective endocarditis. Pol Merkur Lekarski 2008 24: 484-6.

\section{Address for correspondence:}

Beata P. Kraśnicka-Sokół MD, PhD

$3^{\text {rd }}$ Department of Internal Medicine,

Subdivision of Toxicology, AZA Treatment Subdivision,

Subdivision of Nephrology

Praski Hospital of the Transfiguration of Jesus

al. Solidarności 67, 03-401 Warsaw, Poland

Phone: +48 606613901

E-mail: beakrassokol@op.pl 